\title{
THE ATTITUDE SCALE TOWARDS DISTANCE NURSING EDUCATION (astDNE)
}

\author{
Lecturer Dr. Belgin BOZ YUKSEKDAG \\ Anadolu University \\ College of Open Education \\ Eskisehir, TURKEY \\ Assoc. Prof. Dr. Gul UNSAL BARLAS \\ Marmara University, \\ Faculty of Health Sciences, \\ Istanbul, TURKEY
}

\begin{abstract}
In this study, a measurement is seen as an instrument to measure the attitudes of the nurses towards the distance nursing education was developed. The study population consist of nurses who working in two hospitals of the ministry of health and two special hospitals in Istanbul. The sample of the study consisted of 194 nurses who agreed to participate in this study. The scale total cronbach alpha coefficient was found .94, test-retest reliability coefficient .89 . The correlations of each item with total point were between .49 and .69. In factor analysis done with varimax rotation for construct validity, whose eigenvalue is over 1 , explaining $65.02 \%$ of total variability, 5 factors consisting of 25 items was obtained the scale. These factors are called "Interaction", "Learning Styles", "Support Services", "Interaction Tools" and "Content Presentation". Consequently, findings show that The Attitude Scale towards Distance Nursing Education (astDNE) is a valid and reliable instrument.
\end{abstract}

Keywords: The attitude scale, distance nursing education, astDNE.

\section{INTRODUCTION}

Because of the increase in health problems in society, the emergence of the disease and new treatment options, the working nurses in hospitals have to update their knowledge and skills (Atack and Rankin, 2002; Piko, 2007). The goal of distance nursing education to students who can not attend formal education is to provide a learning experience equivalent to formal education (White, 2006). Distance education programs provide to access to nurses from their personal computers to course materials in any time of day. In this way, barriers and costs associated with travel are eliminated (Holly, Legg, Mueller and Adelman, 2008). On the otherhand, distance education offers alternative solutions that their information updating as well as a high level of education to nurses (Shea, 2008; Della-Vecchia, 2010). Moving from a student-centered approach, attitudes of the target audience is an important element in the development of distance nursing education programs. However; the attitudes of nurses towards distance nursing education are unknown in Turkey. 
The purpose of this study is to develop the attitude scale towards the distance nursing education. In this study, the attitude was defined as the positive and negative opinions that based on past educational experiences of nurses about distance nursing education.

\section{AIM and METHOD of the RESEARCH}

The study was carried out to develop the attitude scale towards the distance nursing education. The study population consist of nurses who working in two hospitals of the ministry of health and two special hospitals in Istanbul. However; one of the special hospitals did not want to join to this research. So, it was left out of the research population. The total study population consisted of 385 nurses. The sample of the study consisted of 194 nurses who agreed to participate in this study.

\section{Research Hypothesis}

$\mathrm{H}_{1=}$ the Attitude Scale towards Distance Nursing Education is a reliable and valid tool to measure the attitude levels of nurses towards distance nursing education.

\section{Data Collection Tools and Data Collection}

Research data were collected by the researcher with The Attitude Scale towards Distance Nursing Education. The scale was administered to 194 psychiatric nurses in September 2011.

\section{Evaluation of Data}

In data analysis, SPSS version 17 was used. The data were analyzed under two headings:

$>$ Development of the Attitude Scale towards Distance Nursing Education

$>$ The attitudes of psychiatry nurses towards the distance nursing education.

However, in this study, only the development stages of astDNE were given.

\section{FINDINGS}

The development stages of astDNE

\section{Creation of Items and the Opinions of Experts}

Attitudes of the target audience in the creation of distance education programs are an important element to consider.

According to literature, the studies towards distance nursing education have been found to be insufficient in Turkey. Especially, there are no studies towards distance psychiatric nursing education. On the other hand, a measuring tool is absent for determining attitudes of psychiatric nurses towards distance nursing education. For this purpose, while creating scale, firstly related to distance nursing education and distance education literature has been scanned. Attitude scales were revised. A total of 60 scale items were written. These items were presented to experts to ensure content validity. Experts were asked their opinions on expressive style, content, relevance to the subject area of items. According to experts, some items were removed. The final version of the scale consisted of 55 items.

\section{Implementation of Draft Version of the Scale}

Pre-tests should be tried on a small group, which is not included in the sample. The small group should have similar features with examples (Tezbasaran, 1996; Karaca, 2004). 
The draft scale was implemented to 32 nurses working in Eskisehir who had similar characteristics with the nurses in the sample.

The nurses were asked their opinions towards understandability of the questions, answering time, and applicability of the form. The nurses noted that items were understandable, and the answering time was enough. Then it was passed into the implementation phase of the study. In September 2011, 55-items draft scale was implemented to 194 psychiatry nurses who had working in Istanbul.

\section{Stage of the Construct Validity}

Factor analysis was used to examine the construct validity. In this study, explanatory factor analysis was used to determine the unknown attitudes of psychiatric nurses towards the distance nursing education (Kan, 2007). Before explanatory factor analysis, the data set should be examined for suitability for factor analysis (Akbulut, 2010; Büyüköztürk, 2011). For the purpose, sample size and the method of determining factors were analyzed (Field, 2005; Büyüköztürk, 2011). For the sample size, it was analyzed Kaiser-Meyer-Olkin and Bartlett's test (Table: 1).

Table: 1

Kaiser-Meyer-Olkin and Bartlett's test

\begin{tabular}{lcc}
\hline KMO & & .913 \\
\hline \multirow{3}{*}{ Bartlett Testi } & $X^{2}$ & 2798.76 \\
& Sd & 300 \\
& $P$ & .000 \\
\hline
\end{tabular}

In this study, Kaiser Meyer Olkin (KMO) value were found 0.913, Bartlett's test 2798.76 $(p<0.05)$. According to results, the sample size was sufficient and the data was suitable for factor analysis. As to the method of determining factors, this method was used to describe the relationship between variables with the best and the least number of factors. There are many factors determining method. The most common methods is the principal component analysis. Apart from this, there are three methods for determining the number of factors. The first method is called the Kaiser criteria. The factors with eigenvalues 1 and above were taken to the scale. Another method is Catell's scree test. Each of eigenvalue was shown in a graph. According to the breaking point of continuity was decided the number of factors of the scale (figure: 1). 


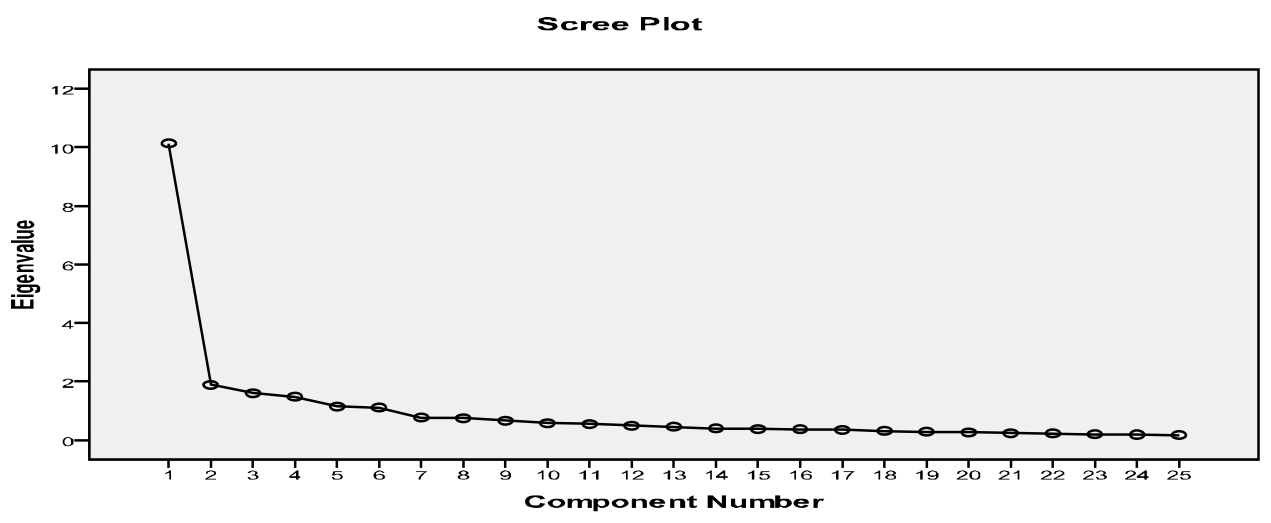

Figure: 1

Catell's scree test

According to line graph, it was showed a breaking point in 5th factor. After this point, a decrease was observed. According to these results, it was decided that the scale can be limited to the five-factor (Figure: 1).

In the factor analysis, it explained the variance of the first factor alone is around 0.30 and the explained variance and the eigenvalues of the following factors declined sharply, then it indicates that the scale has a single-factor structure (Table: 2 ).

Table: 2

The rations eigenvalues and explained variance of the sub-scales

\begin{tabular}{lccc}
\hline Subscales & Eigenvalue & explained variance \% & Cumulated variance \\
\hline 1. Subscale & 10.13 & 40.52 & 40.52 \\
2. Subscale & 1.88 & 7.53 & 48.06 \\
3. Subscale & 1.61 & 6.43 & 54.49 \\
4. Subscale & 1.48 & 5.92 & 60.41 \\
5. Subscale & 1.15 & 4.62 & 65.02 \\
\hline
\end{tabular}

According to table 2, the eigenvalue of the first factor is $\mathbf{1 0 . 1 3}$, the explained variance of first factor is $\mathbf{4 0 . 5 2}$. Eigen value of the second factor is $\mathbf{1 . 8 8}$, the explained variance of second factor 7.53. Eigen value of the third factor is 1.61 , the explained variance of third factor is 6.43 .

Eigen value of the fourth factor is 1.48, the explained variance of fourth factor is 5.92. Eigen value of the fifth factor is 1.15 , the explained variance of fifth factor is 4.62 . The total variance of the scale was $65.02 \%$. The higher the variance ratio, the stronger is the factor structure of the scale (Gorsuch, 1974; Lee and Comrey, 1979). In social sciences, $40 \%-60 \%$ are considered ideal variance ratios (Büyüköztürk, 2011). According to the results, the obtained variance ratio, is said to be sufficient or in the ideal level (Table 2).

Another method used in the selecting of items is factor load value. It explains relationship between items and subscales. Factor load value is $\mathbf{0 . 4 5}$ or higher than 0.45 is a good measure 
for the item selection (Büyüköztürk, 2011). In this study, the least load value was 0.45 . Based on these criteria, Principal Component Analysis applied to the 55-item. Items with low variance and factor load less than forty-five percent were removed from the scale.

These items were the 1st, 5th, 6th, 8th, 11th, 12th, 22nd, 25th, 28th and 36th. So, it was remained 45 items on the scale. Varimax rotation was applied to interpret easier. The 2 nd, 3rd, 7th, 13th, 15th, 21th, 23th, 24th, 32th, 33th, 37th, 38th, 39th, 41th, 43th, 44th, 45th, 46th, 47th and 55th items with high-factor load value were removed from the scale.

So, the scale has become to a 6 factors and 25 -item scale. The number of factors was limited to 5 factors because the last factor had two items. At the end, it was obtained a 5 factor and 25item scale. Item-Total Correlations, Principal Components and Factor Analysis Results in the Load Values of this scale were presented in table: 3.

Table: 3

Item-Total Correlations, Principal Components andFactor Analysis Results in the Load Values

\begin{tabular}{|c|c|c|c|c|c|c|c|c|c|}
\hline 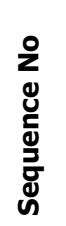 & 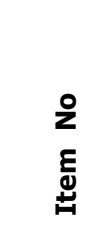 & 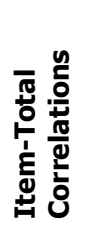 & 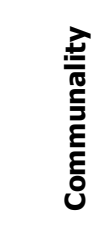 & 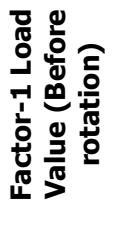 & 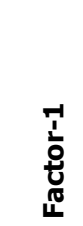 & 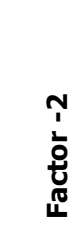 & $\begin{array}{l}\text { m } \\
\text { to } \\
\text { ț } \\
\text { జ }\end{array}$ & 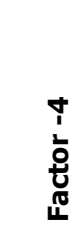 & 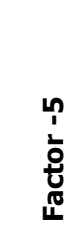 \\
\hline 1. & M-04 & .46 & .58 & .50 & .07 & .29 & .07 & .16 & .69 \\
\hline 2. & M-09 & .53 & .57 & .57 & .20 & .38 & .62 & .02 & -.02 \\
\hline 3. & M-10 & .46 & .59 & .51 & .37 & .25 & .61 & -.08 & -.13 \\
\hline 4. & $M-14$ & .56 & .55 & .60 & .32 & .64 & .12 & .16 & .00 \\
\hline 5. & M-16 & .60 & .62 & .64 & .09 & .67 & .12 & .32 & .21 \\
\hline 6. & M-17 & .56 & .71 & .61 & -.01 & .76 & .30 & .10 & .18 \\
\hline 7. & M-18 & .57 & .66 & .61 & .12 & .76 & .11 & .17 & .16 \\
\hline 8. & M-19 & .63 & .67 & .66 & .21 & .72 & .10 & .16 & .27 \\
\hline 9. & M-20 & .66 & .59 & .70 & .37 & .60 & .21 & .21 & .09 \\
\hline 10. & M-26 & .54 & .62 & .57 & .24 & .23 & -.01 & .71 & .08 \\
\hline 11. & M-27 & .54 & .65 & .60 & .19 & -.01 & .67 & .22 & .34 \\
\hline 12. & M-29 & .66 & .72 & .69 & .24 & .24 & .19 & .74 & .14 \\
\hline 13. & M-30 & .62 & .66 & .66 & .19 & .22 & .28 & .70 & -.08 \\
\hline 14. & M-31 & .69 & .69 & .73 & .20 & .19 & .59 & .49 & .17 \\
\hline 15. & M-34 & .69 & .72 & .74 & .14 & .27 & .62 & .46 & .17 \\
\hline 16. & M-35 & .49 & .57 & .53 & .22 & .10 & .06 & .70 & .13 \\
\hline 17. & M-40 & .63 & .79 & .68 & .15 & .15 & .75 & .16 & .40 \\
\hline 18. & $M-42$ & .60 & .68 & .65 & .21 & .14 & .36 & .23 & .66 \\
\hline 19. & $M-48$ & .63 & .69 & .67 & .37 & .36 & .20 & .04 & .61 \\
\hline 20. & M-49 & .66 & .65 & .70 & .69 & .18 & .21 & .09 & .05 \\
\hline 21. & M-50 & .63 & .66 & .67 & .73 & .19 & .12 & .18 & .22 \\
\hline 22. & M-51 & .49 & .48 & .53 & .64 & .10 & .18 & .17 & .00 \\
\hline 23. & M-52 & .61 & .74 & .65 & .68 & .25 & -.08 & .17 & .42 \\
\hline 24. & M-53 & .65 & .70 & .69 & .72 & .14 & .32 & .24 & .02 \\
\hline 25. & M-54 & .65 & .72 & .68 & .77 & .11 & .15 & .25 & .20 \\
\hline
\end{tabular}


According to the table 3, the load factor values of items in the first sub-scale was .64-.77, in the second sub-scale was between .60-.76; in the third sub-scale was .59-.75, in the fourth subscale was .70-.74 and in the fifth sub-scale between found .61-.69.

This findings indicated that the scale composed of items which were highly correlated with each other, that it also measures attitudes towards distance nursing education, and has a strong factor structure of the scale.

The sub-scales of astDNE was called considering the meaning of attitude expressions (table 4). The first sub-scale was called "interaction", the second one was named "learning styles", the third one was named "support services", the forth one was named "interaction tools", and the fifth one was called "content presentation".

Table: 4

The Subscales of the astDNE and Items

\begin{tabular}{ll}
\hline Subscales & Items No \\
\hline 1. Interaction & $49,50,51,52,53,54$ \\
2. Learning styles & $14,16,17,18,19,20$ \\
3. Support services & $9,10,27,31,34,40$ \\
4. Interaction tools & $26,29,30,35$ \\
5. Content Presentation & $4,42,48$ \\
\hline
\end{tabular}

According to Table: 4, the 1st, 2nd and 3th subscale contain six items. The fourth subscale contains four items, and the fifth subscale contains three items.

\section{The Reliability Stage of astDNE}

In determining of the reliability of the measurement tool were used techniques such as calculation of coefficient of internal consistence (Cronbach Alpha), item-total correlations and test-retest methods.

In this study, Cronbach Alpha of the draft scale was found 0.92 .

This value indicates that the draft scale was reliable. Another method to measure reliability is the item-total correlation.

Item-total correlation illustrates the relationship between the scores obtained from items and item total correlation. In selecting of the items, item-total correlation coefficient was based on criteria that the value is above 0.20 (Tavsancıl and Keser, 2002; Büyüköztürk, 2011).

The item-total correlation coefficient of each item on the scale was found to be over 0.20 . This finding shows 55-items have distinctiveness. Another method of testing reliability is test-retest reliability.

After four weeks the scale was applied again and test re-test correlation coefficient was found to be 0.89 . 
This result shows that in terms of time the scale is a consistent scale. The reliability findings of astDNE were given in table 5 and table 6 below.

Table: 5

Reliability Values of astDNE

\begin{tabular}{lcc}
\hline The Subscales & $\begin{array}{c}\text { Cronbach Alfa } \\
(\%)\end{array}$ & $\begin{array}{c}\text { Item-Total } \\
\text { Corelation(\%) }\end{array}$ \\
\hline Interaction & .88 & $.56-.75$ \\
Learning Styles & .87 & $.59-73$ \\
Support Services & .85 & $.51-.75$ \\
Interaction Tools & .82 & $.59-.72$ \\
Content Presentation & .75 & $.53-.61$ \\
Total of Scale & .94 & $.46-.69$
\end{tabular}

According to table 5, the scale total cronbach alpha coefficient was found .94. Item total correlation was between .46-.69.

Table: 6

Item Analysis Results toward the total of astDNE

\begin{tabular}{|c|c|c|c|c|}
\hline & $\begin{array}{c}\text { Scale Mean If Item } \\
\text { Deleted }\end{array}$ & $\begin{array}{c}\text { Scale } \\
\text { Variance If } \\
\text { Item deleted }\end{array}$ & $\begin{array}{l}\text { Corrected } \\
\text { Item total } \\
\text { Correlation }\end{array}$ & $\begin{array}{l}\text { Cronbach's Alpha } \\
\text { If Item Deleted }\end{array}$ \\
\hline 4 & 46.93 & 184.13 & 0.46 & 0.94 \\
\hline 9 & 46.87 & 181.93 & 0.53 & 0.93 \\
\hline 10 & 46.57 & 181.62 & 0.45 & 0.94 \\
\hline 14 & 46.61 & 178.53 & 0.56 & 0.93 \\
\hline 16 & 46.65 & 178.61 & 0.59 & 0.93 \\
\hline 17 & 46.81 & 180.96 & 0.56 & 0.93 \\
\hline 18 & 46.89 & 182.25 & 0.57 & 0.93 \\
\hline 19 & 46.65 & 179.63 & 0.62 & 0.93 \\
\hline 20 & 46.47 & 175.71 & 0.65 & 0.93 \\
\hline 26 & 46.46 & 179.31 & 0.53 & 0.93 \\
\hline 27 & 47.06 & 182.43 & 0.54 & 0.93 \\
\hline 29 & 46.64 & 178.33 & 0.65 & 0.93 \\
\hline 30 & 46.52 & 177.77 & 0.62 & 0.93 \\
\hline 31 & 46.85 & 180.04 & 0.68 & 0.93 \\
\hline 34 & 46.84 & 179.33 & 0.69 & 0.93 \\
\hline 35 & 46.27 & 178.02 & 0.49 & 0.94 \\
\hline 40 & 46.97 & 180.37 & 0.63 & 0.93 \\
\hline 42 & 46.80 & 180.79 & 0.60 & 0.93 \\
\hline 48 & 46.81 & 180.57 & 0.63 & 0.93 \\
\hline 49 & 46.69 & 178.66 & 0.65 & 0.93 \\
\hline 50 & 46.52 & 178.64 & 0.63 & 0.93 \\
\hline 51 & 46.36 & 182.26 & 0.49 & 0.94 \\
\hline 52 & 46.52 & 177.69 & 0.61 & 0.93 \\
\hline 53 & 46.75 & 178.52 & 0.65 & 0.93 \\
\hline 54 & 46.71 & 178.48 & 0.64 & 0.93 \\
\hline
\end{tabular}


According to the table 6, Cronbach's Alpha value did not decrease when item was deleted. So, the reliability of the astDNE did not decline.

The corrected item-total correlation was found between .45 and .69.

If item-total correlation is positive and high, that means that items measure similar behavior, and shows that the scale has a high internal consistency.

These high rates pointed out those 25 -items have distinctiveness.

\section{Test-retest Reliability}

The test-retest reliability is applied twice to the same group (Ozbek, 2010; Büyüköztürk, 2011).

The correlation between two results indicates the reliability of the scale. The tests were applied to 33 nurses. The second test was performed after four weeks to the same persons (Table 7).

Table: 7

Test-retest reliability $(\mathbf{N}=33)$

\begin{tabular}{ccccc}
\hline & Mean & Sd & $* R$ & P \\
\hline First-test & 183.8788 & 19.67352 & .885 & .000 \\
\hline Second-test & 179.6364 & 17.87949 & & \\
\hline \multicolumn{5}{c}{$*$ R $=$ Pearson's correlation test }
\end{tabular}

According to table 7, the correlation between the two applications was .885 . This finding showed that the two application scores were similar. In other words, in terms of time the scale was consistent.

\section{RESULTS}

Consequently, findings showed that The Attitude Scale Towards Distance Nursing Education (astDNE) is a valid and reliable instrument. The research findings supported the hypothesis 1.

\section{BIODATA and CONTACT ADDRESSES of AUTHORS}

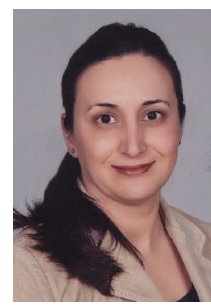

Belgin BOZ YUKSEKDAG has been working at Anadolu University College of Open Education Testing \& Research Center as a lecturer doctor. She graduated from the School of Nursing of Hacettepe University in 1990. She earned her MS degree from the Graduate School of Istanbul University (Health Sciences Department), Internal Medicine Nursing in 1995, and also the MA degree from the Graduate School of Anadolu University (Distance Education Department), in 2008. She earned her PhD degree from the Graduate School of Marmara University (Health Sciences Department), Psychiatry Nursing, in 2013.

\section{Belgin BOZ YUKSEKDAG}

Anadolu University Testing Research Department

Yunus Emre Campus, 26470 Eskisehir TURKEY

Tel: 0 (222) 3350580-2713

Mobile: 05545140122

Email: bboz@anadolu.edu.tr 
Gul UNSAL BARLAS is an associate professor in department of psychiatric nursing at the Faculty of Health Sciences of Marmara University. She graduated from the School of Nursing of Florence Nightingale in 1983. She earned her MS degree from the Graduate School of Marmara University (Health Sciences Department) in 1998. She earned her PhD degree from the Graduate School of Marmara University (Health Sciences Department), Psychiatry Nursing, in 2004.

\section{GuI UNSAL BARLAS}

Marmara University, the Faculty of Health Sciences

Tel: 0 (216)3302070-1149

Mobile: 05332436882

Email: gunsal@marmara.edu.tr

\section{REFERENCES}

Akbulut, Y. (2010). Sosyal Bilimlerde SPSS Uygulamaları. Sık Kullanılan İstatistiksel Analizler ve Açıklamalı SPSS Çözümleri [SPSS Applications in the Social Sciences. Commonly Used Statistical Analysis and Explanatory SPSS Solutions], Ideal Kültür\&Yayıncılık.

Atack, L. and Rankin, J. (2002). A descriptive study of registered nurses' experiences with webbased learning. Journal of Advenced Nursing, 40(4):457-465.

Büyüköztürk, S. (2011). Sosyal bilimler İçin Veri Analizi El Kitabı. [Handbook of Data Analysis for the Social Sciences], (13. Baskı), Pegem Akademi.

Comrey, A. L. and Lee, H. B. (1992). A First Course in Factor Analysis. $2^{\text {nd }}$ edition. Hillsdale, NJ: Erlbaum.

Della-Vecchia, E. T. (2010). The Phenomenon of Learning: The Lived Experience Of Distance Education Baccalaureate Nursing Students. Capella University, PhD thesis, (Advisor: Dr.Chris Calvin).

Field, A. (2005). Discovering Statistics Using SPSS. $2^{\text {nd }}$ edition. London: Sage Publication.

Gorsuch, R. L. (1974). Factor Analysis. Philadelphia: Saunders.

Holly, C., Legg, T. J., Mueller, D. and Adelman, D. S. (2008). Online teaching: Challenges for a new faculty role, Journal of Professional Nursing, 24(4):254-258.

Kan, A. (2007). Ölçme Araçlarında Bulunması Gereken Nitelikler. İçinde: Eğitimde Ölçme ve Değerlendirme [Measurement and Evaluation in Education]. Ed: Atılgan H, 2. Baskı, Anı Yayıncilık, Ankara, s.24-72.

Karaca, E. (2004). Öğretmen Adaylarının Ölçme ve Değerlendirme Yeterliklerine İlişkin Algıları [The Perceptions of Teacher Candidates Towards Assessment and Qualifications). Yayın No: 1549. Eskişehir, s. 82-86, Anadolu Üniversitesi. 
Ozbek, O. Y. (2010). Ölçme Araçlarında Bulunması İstenen Nitelikler. İçinde: Eğitimde Ölçme ve Değerlendirme [Measurement and Evaluation in Education]. Ed: Tekindal S, 2. Baskı, Pegem Akademi, Ankara, s. 44-84.

Piko, B. F. (2007). New challenges for mental health in public health. International Journal of Public Health, 52(3):127-128.

Shea, C. A. (2008). Psychiatric nursing education at a distance. Journal of the American Psychiatric Nurses Association, 14(1):36-38.

Tavşancıl, E. and Keser, H. (2002). Internet Kullanımına Yönelik Likert Tipi Bir Tutum Ölçeğinin Geliştirilmesi [Development of A Likert Type Attitude Scale Towards Internet Usage], Eğitim Bilimleri Dergisi, 1(1): 79-100.

Tezbaşaran, A. A. (1996). Likert Tipi Ölçek Geliştirme Kılavuzu [Likert Type Scale Development Guide], Ankara: TPD Yayınları.

White, L. H. (2006). Canfield Learning Style Inventory as A Predictor Of Success In Distance Learning Program Versus Traditional Learning Program In An Associate Degree Nursing Program. Touro University International, PhD thesis, (Advisor: Dr. Sally Hutslar). 